\title{
Structurally diverse MDM2-p53 antagonists act as modulators of MDR-1 function in neuroblastoma
}

\author{
L Chen ${ }^{1}$, Y Zhao ${ }^{1}$, G C Halliday ${ }^{1}$, P Berry ${ }^{1}$, R F Rousseau ${ }^{2}$, S A Middleton ${ }^{3}$, G L Nichols ${ }^{3}$, F Del Bello ${ }^{4}$,
} A Piergentilii ${ }^{4}$ D R Newell ${ }^{1}$, J Lunec ${ }^{1}$ and D A Tweddle ${ }^{*, 1}$

${ }^{1}$ Newcastle Cancer Centre, Northern Institute for Cancer Research, Newcastle University, Newcastle upon Tyne NE2 4HH, UK; ${ }^{2}$ Genentech Inc., 1 DNA Way, South San Francisco, CA 94080, USA; ${ }^{3}$ Hoffmann-La Roche Inc., 340 Kingsland Street, Nutley, NJ 07110, USA and ${ }^{4}$ Medicinal Chemistry Unit, School of Pharmacy, University of Camerino, via S. Agostino 1, Camerino 62032, Italy

Background: A frequent mechanism of acquired multidrug resistance in human cancers is overexpression of ATP-binding cassette transporters such as the Multi-Drug Resistance Protein 1 (MDR-1). Nutlin-3, an MDM2-p53 antagonist, has previously been reported to be a competitive MDR-1 inhibitor.

Methods: This study assessed whether the structurally diverse MDM2-p53 antagonists, MI-63, NDD0005, and RG7388 are also able to modulate MDR-1 function, particularly in p53 mutant neuroblastoma cells, using XTT-based cell viability assays, western blotting, and liquid chromatography-mass spectrometry analysis.

Results: Verapamil and the MDM2-p53 antagonists potentiated vincristine-mediated growth inhibition in a concentrationdependent manner when used in combination with high MDR-1-expressing p53 mutant neuroblastoma cell lines at concentrations that did not affect the viability of cells when given alone. Liquid chromatography-mass spectrometry analyses showed that verapamil, Nutlin-3, MI-63 and NDD0005, but not RG7388, led to increased intracellular levels of vincristine in high MDR-1expressing cell lines.

Conclusions: These results show that in addition to Nutlin-3, other structurally unrelated MDM2-p53 antagonists can also act as MDR-1 inhibitors and reverse MDR-1-mediated multidrug resistance in neuroblastoma cell lines in a p53-independent manner. These findings are important for future clinical trial design with MDM2-p53 antagonists when used in combination with agents that are MDR-1 substrates.

MDM2-p53 antagonists are a novel class of anticancer agents that are currently in preclinical and/or early-phase clinical evaluation for the treatment of both haematological and solid malignancies. This class includes cis-imidazolines, spiro-oxindoles, benzodiazepinediones, isoindolinones, isoquinolinones and thiophenes that act by disrupting the interaction between p53 and its critical negative regulator MDM2 to reactivate wild-type (wt) p53 (Chen and Tweddle, 2012; Miyazaki et al, 2013). Nutlins were the first potent and selective inhibitors of the MDM2-p53 interaction (Vassilev et al, 2004), in particular Nutlin-3 has been extensively evaluated in vitro and in vivo in several types of human cancers, including neuroblastoma (reviewed by (Chen and Tweddle, 2012)). Overall, MDM2-p53 antagonists have been shown to activate the p53 pathway, triggering p53-dependent cell cycle arrest and/or apoptosis, while inducing a reversible cell cycle arrest in normal cells (Cheok et al, 2011; Vassilev, 2004).

Hoffmann-La Roche were the first to report potent and selective small molecule MDM2-p53 binding antagonists, establishing in vitro and in vivo proof of efficacy as anticancer agents with the cis-imidazoline (Nutlin) compound series (Vassilev et al, 2004). 
Subsequently, Hoffman-La Roche have developed alternative compound series with more suitable in vivo properties and have been the first pharmaceutical company to enter their lead candidates ((RG7112 (R05045337) and RG7388 (R05503781)) in clinical trials, evaluating them both as single agents and also in combination with doxorubicin (www.clinicaltrials.gov; NCT01462175, NCT01677780 and NCT01605526; Ray-Coquard et al, 2012). More recently, lead candidates of this class from other pharmaceutical companies such as Daiichi Sankyo (Tokyo, Japan) (www.clinicaltrials.gov; NCT01877382), Amgen (Thousand Oaks, CA, USA) (www.clinicaltrials.gov; NCT01723020, NCT02016729), Sanofi (Paris, France)/Merck KGaA (Darmstadt, Germany) (www.clinicaltrials.gov; NCT01636479, NCT01985191) and Novartis (Cambridge, MA, USA) (www.clinicaltrials.gov; NCT01760525, NCT02143635) have entered early-phase trials as single agents and in combination.

To date, several p53-independent functions of Nutlin-3 have also been reported, including disruption of the MDM2-p73 interaction (Lau et al, 2008), sensitising p53-deficient chemoresistant cells to chemotherapy-induced apoptosis via upregulation of TAp73 and E2F1 (Ambrosini et al, 2007; Peirce and Findley, 2009), as well as acting as a competitive Multi-Drug Resistance Protein 1 (MDR-1) inhibitor and reversing MDR-1-mediated drug resistance (Michaelis et al, 2009).

Acquired multidrug resistance is a major challenge in the successful treatment of cancers and can occur by increased expression of ATP-binding cassette (ABC) transporters, such as MDR-1, a $170-\mathrm{kDa}$ transmembrane efflux pump encoded by the MDR-1 (ABCB1) gene. MDR-1-mediated efflux of chemotherapeutics out of the cell leads to decreased intracellular concentrations and reduced drug efficacy. Overexpression of MDR-1 has been shown to confer resistance to chemotherapies such as vinca alkaloids, anthracyclines and taxanes. Modulating $\mathrm{ABC}$ transporter activity to restore sensitivity and overcome multidrug resistance has been well studied. To date, several compounds including verapamil and cyclosporine have been shown to inhibit MDR-1 function and some of these have entered clinical trials (Yu et al, 2013).

Neuroblastoma is a rare embryonal malignancy of the sympathetic nervous system that accounts for $15 \%$ of childhood cancer-related mortality (Park et al, 2010). Over $50 \%$ of patients present with high-risk metastatic disease at the time of diagnosis, and despite an initial response to intensive multimodal therapy, relapse with chemoresistant disease is common. The overall longterm survival of high-risk patients is currently less than $50 \%$, with those that survive often having long-term toxicities. Previous studies have found high MDR-1 expression in neuroblastoma, and in some reports this was shown to have prognostic importance (Chan et al, 1991; Benard et al, 1994; Haber et al, 1997; de Cremoux et al, 2007; Oue et al, 2009).

Using p53 mutant and wt neuroblastoma cell lines established at relapse as a model of chemoresistant disease, the present study aimed to assess whether structurally diverse MDM2-p53 antagonists, namely Nutlin-3 (cis-imidazoline), NDD0005 (isoindolinone), MI-63 (spiro-oxindole) and RG7388 (pyrrolidine) (Ding et al, 2006; Watson et al, 2011; Ding et al, 2013) are able to act as MDR-1 inhibitors and sensitise cells to vincristine-induced cytotoxicity. A greater understanding of the properties of this class of novel cancer therapeutics will facilitate their future design, clinical development and incorporation into current treatment regimens for patients with neuroblastoma and other cancers.

\section{MATERIALS AND METHODS}

Chemicals and ELISA-based MDM2-p53-binding screening. Nutlin-3 was purchased from Enzo Life Sciences Ltd (Exeter, UK).
RG7388 was a gift from Roche-Genentech (Nutley, NJ, USA; Ding et al, 2013). MI-63 was synthesised as previously described (Ding et al, 2006), as was NDD0005 (Watson et al, 2011). The concentration of the latter compounds required to inhibit the binding between MDM2 and p53 by $50 \%$ $\left(\mathrm{IC}_{50}\right.$ values) was determined using an ELISA-based method as previously described (Hardcastle et al, 2005). The chemical structures and $\mathrm{IC}_{50}$ values of the MDM2-p53 antagonists are shown in Figure 1A. Vincristine, cisplatin and doxorubicin were all purchased from Sigma-Aldrich (Dorset, UK). Verapamil was purchased from Calbiochem (Merck KGaA)

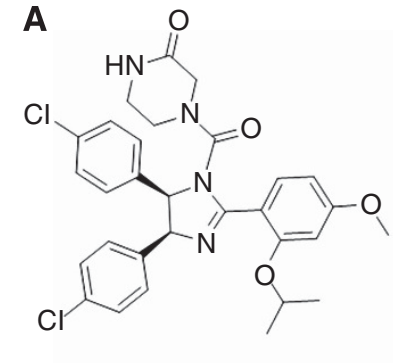

Nutlin-3
${ }^{\star} \mathrm{IC}_{50}=51 \pm 29 \mathrm{nM}$<smiles>O=C1c2cccc(Cl)c2[C@@](OCC2(CO)CC2)(c2ccc(Cl)cc2)N1Cc1ccc([N+](=O)[O-])cc1</smiles>

NDD0005

$\mathrm{IC}_{50}=31 \pm 13 \mathrm{nM}$<smiles>CC(C)(C)C[C@@H]1N[C@H](C(=O)NCCN2CCOCC2)[C@H](c2cccc(Cl)c2F)[C@@]12C(=O)Nc1cc(Cl)ccc12</smiles>

MI-63

$\mathrm{IC}_{50}=26 \pm 8 \mathrm{nM}$

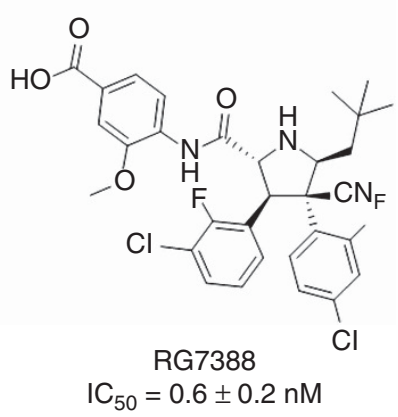

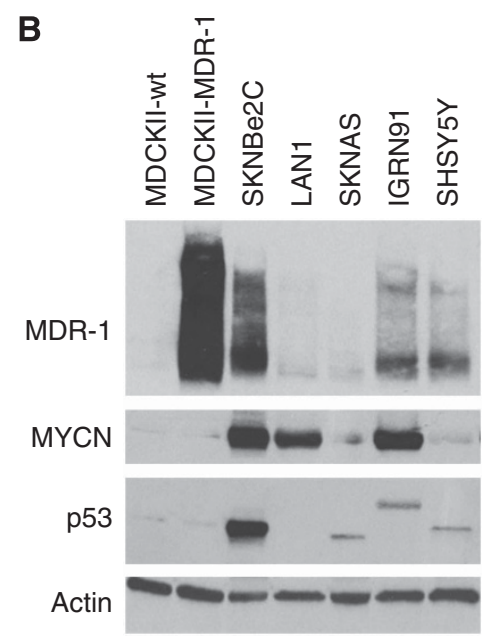

Figure 1. The chemical structures of MDM2-p53 antagonists Nutlin-3, NDD0005, MI-63, and RG7388, and MDR-1 expression in a panel of neuroblastoma cell lines established at relapse. (A) The chemical structures and corresponding $\mathrm{IC}_{50}$ values of Nutlin-3, NDD0005, MI-63 and RG7388. *This is the IC 50 value for the active enantiomer Nutlin-3a. (B) Western blot analysis showing the expression levels of MDR-1, p53 and MYCN in p53 mutant (SKNBe2C, LAN1, SKNAS and IGRN91) and wt (SHSY5Y) neuroblastoma cell lines. MDCKII-MDR-1 cells are stably transfected with human MDR-1 and were used as a positive control. Actin was used as a loading control. 
and dissolved in sterile distilled water. Cisplatin was dissolved in dimethylformamide, and all other drugs were dissolved in dimethyl sulfoxide (DMSO).

Cell lines. Human neuroblastoma cell lines used were p53 mutant SKNBe2C, SKNAS, LAN1 and IGRN91 and p53 wt SHSY5Y cells. All cell lines were established post-chemotherapy and SKNBe2C, LAN1 and IGRN91 cells are MYCN-amplified (Chen and Tweddle, 2012). All neuroblastoma cell lines were obtained between 1996 and 2007 and were validated upon receipt using cytogenetic analysis courtesy of Dr Nick Bown (NHS Department of Cytogenetics, Institute of Genetic Medicine, Newcastle upon Tyne, UK). Madin-Darby canine kidney cell lines MDCKII-wt and MDCKII-MDR-1 were obtained from the originator Alfred Schinkel (Netherlands Cancer Institute). MDR-1 cells are stably transfected with human MDR-1 (Bakos et al, 1998). Neuroblastoma cells were cultured in RPMI-1640 (Sigma-Aldrich) supplemented with 10\% (v/v) FCS (Gibco, Life Technologies Ltd, Paisley, UK). Canine cells were cultured in DMEM supplemented with $10 \%$ FCS, 100 units $\mathrm{ml}^{-1}$ penicillin and $100 \mu \mathrm{g} \mathrm{ml}^{-1}$ streptomycin (Sigma-Aldrich). All cell lines were routinely tested for Mycoplasma and confirmed to be negative. Cells were maintained at $37^{\circ} \mathrm{C}$ in a humidified incubator with $5 \% \mathrm{CO}_{2}$.

Growth inhibition assays. Cells were seeded in 96-well plates (Corning, VWR International Ltd, Lutterworth, UK), allowed to adhere overnight before treatment with MDM2-p53 antagonists or chemotherapy agents alone, or in combination for $72 \mathrm{~h}$. Growth inhibition was assessed using the XTT cell proliferation assay (Roche, Burgess Hill, UK) according to the manufacturer's instructions or sulforhodamine B (SRB) assays as previously described (Gamble et al, 2012). GraphPad Prism v6.0 software (San Diego, CA, USA) was used to calculate $\mathrm{GI}_{50}$ values. For combination treatments, cells were treated with a fixed concentration of verapamil or MDM2-p53 antagonists together with varying concentrations of cytotoxic drugs for $72 \mathrm{~h}$. Experiments were at least $n=3$.

Protein analysis. Whole-cell lysates were harvested as previously described (Tweddle et al, 2001b). Proteins were separated using 4-20\% Mini-PROTEAN TGX Precast Gels (Bio-Rad Laboratories Ltd, Hemel Hempstead, UK) and transferred onto Hybond-C Extra membrane (GE Life Sciences, Little Chalfont, UK). Primary antibodies used were MDR-1 1:200 (Cat No.: sc-13131, Santa Cruz Biotechnology Inc., Dallas, TX, USA), p53 1:1000 (Cat No.: NCL-L-p53-DO7, Leica Microsystems Ltd, Newcastle upon Tyne, UK), MYCN 1:100 (Cat No.: OP13, Merck KGaA), cleaved caspase-3 1:1000 (Cat No.: 9664S, New England Biolabs Ltd, Hitchin, UK), actin 1:500 (Cat No.: A4700, Sigma-Aldrich) and GAPDH 1:500 (Cat No.: sc-25778, Santa Cruz Biotechnology Inc.). Secondary goat anti-mouse/rabbit HRP-conjugated antibodies (Cat No.: P0447/P0448, Dako, Glostrup, Denmark) were used at $1: 1000$. All antibodies were diluted in $5 \%$ milk/1 $\times$ TBS-tween $(w / v)$. Protein detection was performed using enhanced chemiluminescence (GE Life Sciences) and X-ray film (Fujifilm, Bedford, UK).

Liquid chromatography-mass spectrometry (LC-MS). Intracellular drug concentrations were measured using LC-MS. Cells were seeded at $4 \times 10^{5}$ cells per well in six-well plates (Corning), allowed to adhere overnight before treatment with $1 \times$ or $5 \times$ their respective $72-\mathrm{h} \mathrm{GI}_{50}$ concentrations of vincristine alone or in combination with $2 \mu \mathrm{M}$ of verapamil, Nutlin-3, NDD0005, MI-63 or RG7388 for $8 \mathrm{~h}$. After treatment, cells were harvested, lysed in $200 \mu \mathrm{l} 100 \%$ methanol (Fisher Scientific, Loughborough, UK), centrifuged and the supernatant transferred into 2-ml glass vials with 0.4-ml glass inserts (Jaytee Biosciences Ltd, Kent, UK). Eight different concentration standards $(0.0001-200 \mathrm{nM})$ were prepared in methanol. Samples were analysed using an API4000 LC/MS/MS System (AB SCIEX, Warrington, UK) with a Phenomenex Luna $3 \mu$ C8(2) column, $50 \times 2 \mathrm{~mm}$, (Phenomenex, Macclesfield, UK) and a previously validated LC-MS assay (Israels et al, 2010). The mobile phase was $0.02 \mathrm{M}$ ammonium acetate $\mathrm{pH} 5$ (A) and $100 \%$ methanol (B). The flow rate was $400 \mu \mathrm{min}^{-1}$, with a starting composition of $80 \% \mathrm{~A}$, which after $2 \mathrm{~min}$ changed in a linear manner over $5 \mathrm{~min}$ to $10 \% \mathrm{~A}$. A 30 -s gradient returned the composition to $80 \%$ A with a column equilibration time of $3.5 \mathrm{~min}$. The injection volume was $10 \mu \mathrm{l}$. Data were analysed using Analyst software v1.5 (AB SCIEX). Experiments were at least $n=3$. Graphs were generated using GraphPad Prism v6.0 software.

Statistical analyses. All statistical tests were performed using GraphPad Prism v6.0 software and $P<0.05$ taken to be the level of statistical significance.

\section{RESULTS}

MDR-1 expression and sensitivity to chemotherapy in p53 mutant neuroblastoma cell lines. Expression of MDR-1 protein was assessed in a panel of p53 mutant and wt neuroblastoma cell lines of varying MYCN status, and the MDCK cell lines (Figure 1B). MDCKII-wt and MDCKII-MDR-1 were included as a negative and a positive control for MDR-1 expression, respectively. MDCKII-MDR-1 cells that are stably transfected with human MDR-1 expressed very high levels of MDR-1 compared with MDCKII-wt cells. Three out of five neuroblastoma cell lines were found to express high levels of MDR-1; p53 mutant, MYCNamplified SKNBe2C and IGNR91 cells, and p53 wt, non-MYCNamplified SHSY5Y cells. The remaining two p53 mutant cell lines, $M Y C N$-amplified LAN1 and non-MYCN-amplified SKNAS, expressed barely detectable levels of the MDR-1 protein. Consistent with previous reports and compared with p53 wt SHSY5Y cells, SKNBe2C cells expressed high levels of accumulated mutant p53 protein, attributed to a missense mutation at codon 135 (Tweddle et al, 2001a). No p53 protein expression was detected in LAN1 cells as a consequence of a nonsense mutation at codon 182 (Goldschneider et al, 2006) and SKNAS cells expressed a truncated protein because of a deletion of codons 105-125 (Goldschneider et al, 2006). In contrast, IGRN91 cells expressed a protein of greater than predicted molecular weight for wt protein owing to a duplication of exons 7-9 between exons 9 and 10, which results in an extra 321 nucleotides (Goldschneider et al, 2006; Figure 1B).

Sensitivity to chemotherapeutic agents, vincristine and doxorubicin, previously reported to be MDR-1 substrates, was initially determined in p53 mutant neuroblastoma cell lines using XTTbased cell proliferation assays. The concentrations of cytotoxic drugs that led to $50 \%$ inhibition of growth compared with controls $\left(\mathrm{GI}_{50}\right)$ after $72 \mathrm{~h}$ of treatment are shown in Table 1 . In the tested cell lines, high MDR-1 expression was associated with resistance to vincristine and higher $\mathrm{GI}_{50}$ values (p53 mutant high MDR-1 expression vs p53 mutant low MDR-1 expression, $P<0.05$, unpaired $t$-test; Table 1 ). The impact of MDR-1 expression on doxorubicin sensitivity was not significant, and only low MDR-1expressing LAN1 cells had a lower $\mathrm{GI}_{50}$ compared with the high MDR-1-expressing SKNBe2C and IGRN91 cells (Table 1).

Expression of ABC transporter MRP-1 has also previously been linked to resistance to chemotherapies (Szakacs et al, 2006); however, analysis of MRP-1 protein expression in the panel of cell lines used in this study demonstrated that there was no clear difference in MRP-1 expression between the cell lines (Supplementary Figure 1).

Nutlin-3 sensitises high MDR-1-expressing p53 mutant cells to vincristine but not cisplatin. From Table 1, p53 mutant high MDR-1-expressing SKNBe2C and low MDR-1-expressing SKNAS cells were selected for further studies. Verapamil is a calcium channel blocker that has previously been shown to modulate MDR-1-mediated efflux of vincristine and was used as a positive 


\begin{tabular}{|c|c|c|c|c|c|c|c|c|}
\hline & \multicolumn{8}{|c|}{$72-\mathrm{h} \mathrm{Gl}_{50}$} \\
\hline Cell line & $\begin{array}{l}\text { Vincristine } \\
(\mathrm{nm})\end{array}$ & $\begin{array}{c}\text { Doxorubicin } \\
(\mathrm{nM})\end{array}$ & $\begin{array}{l}\text { Cisplatin } \\
(\mu \mathrm{M})\end{array}$ & $\begin{array}{l}\text { Verapamil } \\
\qquad(\mu \mathrm{M})\end{array}$ & $\begin{array}{c}\text { Nutlin-3 } \\
(\mu \mathrm{M})\end{array}$ & $\begin{array}{l}\text { NDD0005 } \\
(\mu \mathrm{M})\end{array}$ & $\begin{array}{c}\mathrm{MI}-63 \\
(\mu \mathrm{M})\end{array}$ & $\begin{array}{c}\mathrm{RG} 7388 \\
(\mu \mathrm{M})\end{array}$ \\
\hline SKNBe2C ${ }^{a}$ & $32.8 \pm 4.0$ & $98.1 \pm 12.7$ & $2.7 \pm 0.2$ & $113.2 \pm 4.0$ & $24.2 \pm 0.4$ & $12.0 \pm 0.8$ & $20.7 \pm 0.4$ & $10.1 \pm 0.2$ \\
\hline IGNR91 & $24.3 \pm 1.7$ & $105.4 \pm 4.6$ & ND & ND & $23.7 \pm 1.8$ & ND & ND & ND \\
\hline SKNAS & $1.5 \pm 0.2$ & $98.8 \pm 3.9$ & $0.8 \pm 0.04$ & $96.5 \pm 5.1$ & $27.0 \pm 2.3$ & $18.3 \pm 0.6$ & $19.2 \pm 0.1$ & $14.0 \pm 0.7$ \\
\hline LAN1 & $2.3 \pm 0.2$ & $51.4 \pm 4.0$ & ND & ND & $27.3 \pm 3.0$ & ND & ND & ND \\
\hline SHSY5Y' & $8.2 \pm 0.6$ & $30.7 \pm 2.7$ & $0.7 \pm 0.1$ & $119.2 \pm 2.7$ & $0.7 \pm 0.1$ & $1.7 \pm 0.2$ & $1.1 \pm 0.1$ & $0.04 \pm 0.004$ \\
\hline MDCKII-wt & ND & ND & ND & ND & $7.2 \pm 3.3$ & $7.1 \pm 1.7$ & $4.8 \pm 3.0$ & $0.15 \pm 0.04$ \\
\hline MDCKII-MDR-1 & ND & ND & ND & ND & $16 \pm 6.2$ & $6.1 \pm 1.1$ & $5.1 \pm 2.4$ & $0.24 \pm 0.04$ \\
\hline
\end{tabular}

control (Tsuruo et al, 1981). Previous findings showing that Nutlin-3 sensitises p53 mutant MDR-1-overexpressing cells to vincristine (Michaelis et al, 2009) were confirmed by testing the sensitivity of SKNBe2C and SKNAS cells to vincristine alone and in combination with 1,2 or $5 \mu \mathrm{M}$ verapamil or Nutlin-3 using XTT assays. The concentrations of verapamil or Nutlin-3 used did not affect the viability or proliferation of the p53 mutant neuroblastoma cells when used as single agents (data not shown). As expected, the results demonstrated that verapamil sensitises high MDR-1-expressing SKNBe2C cells in a concentration-dependent manner to vincristine (Figure 2A). At 1, 2 and $5 \mu \mathrm{M}$, verapamil significantly reduced the $\mathrm{GI}_{50}$ of vincristine in SKNBe2C cells by $10.5-, 19.9-$ and 38.2 -fold $(P<0.05$, paired $t$-test), respectively (Figure $2 \mathrm{~A}$ and Table 2 ). No significant reduction in $\mathrm{GI}_{50}$ was observed in low MDR-1-expressing SKNAS cells (Figure 2B and Table 2). Similarly, Nutlin-3 was found to sensitise SKNBe2C cells but not SKNAS cells to vincristine in a concentration-dependent manner (Figure 2C and D). In SKNBe2C cells at 1, 2 and $5 \mu \mathrm{M}$ Nutlin-3, the $\mathrm{GI}_{50}$ of vincristine was significantly reduced by 2.1 -, 13.7 - and 43.7 -fold $(P<0.05$, paired $t$-test), respectively (Figure $2 \mathrm{C}$ and Table 2$)$. In contrast, there was no significant reduction in the $\mathrm{GI}_{50}$ of vincristine in SKNAS cells (1.2- to 1.3-fold; Figure 2D and Table 2).

The response of high MDR-1-expressing p53 wt SHSY5Y cells to vincristine alone and in combination with verapamil or Nutlin-3 was also assessed. Verapamil was used at 1,2 and $5 \mu \mathrm{m}$ and did not affect the viability or proliferation of SHSY5Y cells; however, Nutlin-3 was used in combination at $0.25 \times, 0.5 \times$ and $1 \times 72-\mathrm{h}$ $\mathrm{GI}_{50}$ concentrations because of the sensitivity of SHSY5Y cells to Nutlin-3 as a result of their wt p53 status. In the presence of 1,2 and $5 \mu \mathrm{M}$ of verapamil, the $\mathrm{GI}_{50}$ of vincristine was significantly reduced by 10.2-, 21.8- and $>50$-fold $(P<0.01$, paired $t$-test), respectively (Supplementary Figure $2 \mathrm{~A}$ and Table 2 ). In addition, the results showed that, although Nutlin-3 treatment led to a slight concentration-dependent sensitisation to vincristine, the magnitude was not as large as observed in SKNBe2C cells (Supplementary Figure 2B and Table 2). The reduced potentiation of vincristine by Nutlin-3 in SHSY5Y cells is most likely due to the lower concentrations of Nutlin-3 used (that is, $<1 \mu \mathrm{M}$ ) compared with the p53 mutant cell lines $(1-5 \mu \mathrm{M})$.

To provide further support that potentiation by Nutlin-3 was because of abrogation of MDR-1-mediated resistance to vincristine, the above experiments were repeated using cisplatin, a cytotoxic agent that is not an MDR-1 substrate (Breier et al, 2013). The results demonstrated that, as expected, Nutlin-3 did not sensitise high MDR-1-expressing SKNBe2C cells or low MDR-1-expressing SKNAS cells to cisplatin (Figures 2E and F, that is, less than 2-fold change in the $\mathrm{GI}_{50}$, Supplementary Table 1).

MDM2 antagonists Nutlin-3, NDD0005 and MI-63 sensitise high MDR-1-expressing cells to vincristine-mediated cytotoxicity. The ability of the structurally diverse MDM2-p53 antagonists NDD0005 (isoindolinone), MI-63 (spiro-oxindole) and RG7388 (pyrrolidine) to sensitise high MDR-1-expressing cells to vincristine in a concentration-dependent manner was then assessed. NDD0005 and MI-63 were both shown to sensitise SKNBe2C cells to vincristine in a concentration-dependent manner (Figure $3 \mathrm{~A}$ and B). At 1, 2 and $5 \mu \mathrm{M}, \mathrm{NDD} 0005$ significantly reduced the $\mathrm{GI}_{50}$ of vincristine by 13.0-, 23.5- and 42.4-fold ( $P<0.05$, paired $t$-test), respectively, and MI-63 by 1.9-, 13.- and 44.4 -fold $(P<0.01$, paired $t$-test), respectively (Figures $3 \mathrm{~A}$ and $\mathrm{B}$ and Table 2$).$ In contrast, RG7388 at 1 and $2 \mu \mathrm{M}$ did not significantly reduce the $\mathrm{GI}_{50}$ of vincristine in the same cells; however, $5 \mu \mathrm{M}$ RG7388 did potentiate vincristine activity by 13.3 -fold, which was of borderline significance $(P=0.052$, paired $t$-test, Figure $3 C$ and Table 2). No concentration-dependent effects were observed for any of the MDM2 antagonists in the low MDR-1-expressing SKNAS cells (Supplementary Figures $3 \mathrm{~A}-\mathrm{C}$ and Table 2). The above experiments were also carried out in high MDR-1-expressing p53 wt SHSY5Y cells. Owing to their p53 wt status, and as with Nutlin-3, NDD0005, MI-63 and RG7388 were also used in combination at $0.25 \times, 0.5 \times$ and $1 \times$ their $72-\mathrm{h} \mathrm{GI}_{50}$ concentrations. Concentration-dependent sensitisation to vincristine was observed (Figures 3D-F and Table 2), which was most significant with NDD0005 (Figure 3D and Table 2). With the exception of NDD0005, the potentiation induced by the MDM2-p53 antagonists in SHSY5Y cells was not as large as that observed for SKNBe2C cells, which is most likely due to the lower absolute concentrations used in these cells compared with the p53 mutant cells (Table 2).

To provide mechanistic evidence of reduced drug efflux following combined treatment with vincristine and MDM2-p53 antagonists, LC-MS was carried out to determine the intracellular levels of vincristine in the presence of verapamil or the different antagonists in SKNBe2C, SKNAS and SHSY5Y cells (Figure 4). Cells were treated with $1 \times$ or $5 \times$ their respective 72 -h vincristine GI $_{50}$ concentrations, alone or in combination with $2 \mu \mathrm{M}$ verapamil, Nutlin-3, NDD0005, MI-63 or RG7388 for $8 \mathrm{~h}$. LC-MS analyses showed that in the presence of verapamil, Nutlin-3, NDD0005 and MI-63, but not RG7388, there was substantial increased accumulation of intracellular vincristine in the high MDR-1-expressing p53 mutant SKNBe2C 

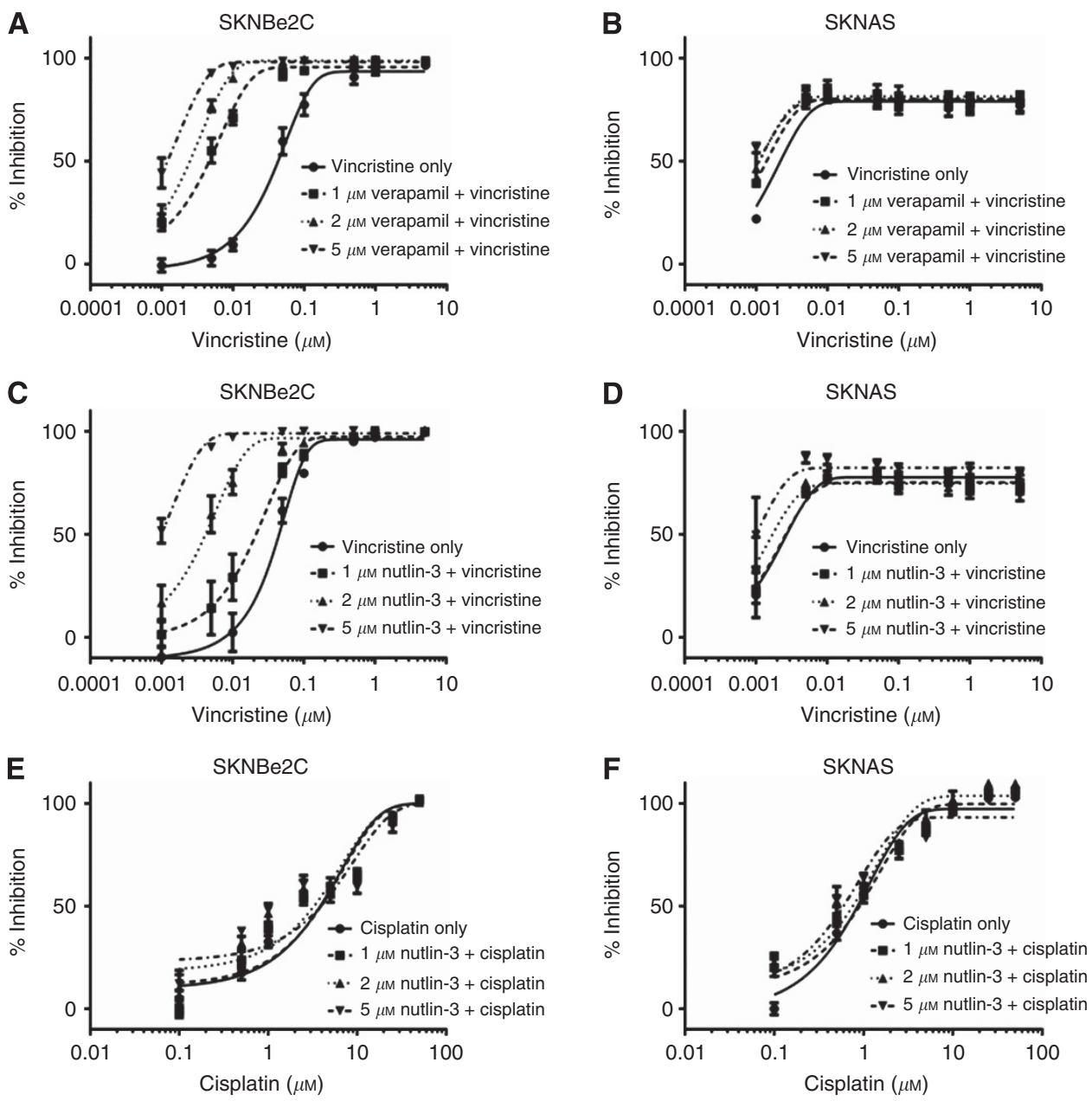

Figure 2. Nutlin-3 sensitises high MDR-1-expressing p53 mutant neuroblastoma cell lines to vincristine but not cisplatin in a concentrationdependent manner. Sensitivity of high MDR-1-expressing SKNBe2C $(\mathbf{A}, \mathbf{C})$ and low MDR-1-expressing SKNAS cells $(\mathbf{B}, \mathbf{D})$ to treatment for $72 \mathrm{~h}$ with vincristine alone or in combination with 1, 2, or $5 \mu \mathrm{m}$ verapamil or Nutlin-3, and (E) SKNBe2C and (F) SKNAS cells to treatment for $72 \mathrm{~h}$ with cisplatin alone or in combination with 1, 2 or $5 \mu \mathrm{m}$ Nutlin-3. Data are shown as the average of at least three independent experiments and error bars represent s.e.m.

(Figure 4A) and p53-wt SHSY5Y cells (Figure 4B), but not in p53 mutant low MDR-1-expressing SKNAS cells (Figure 4C). LC-MS was also used to confirm that verapamil and the MDM2 antagonists were detectable within the cell (data not shown).

MDR-1 protein expression after treatment for $8 \mathrm{~h}$ with $2 \mu \mathrm{M}$ verapamil, Nutlin-3, NDD0005, MI-63 or RG7388 confirmed that the intracellular accumulation of vincristine was not due to decreased MDR-1 expression induced by treatment with the latter compounds (Figure 4D). As expected, mutant p53 expressed in SKNBe2C and SKNAS cells remained unaffected by MDM2-p53 antagonist treatment, but induced p53 stabilisation in p53 wt SHSY5Y cells (Figure 4D).

To determine whether, in the presence of verapamil or MDM2 antagonists, there was increased vincristine-mediated apoptosis, cells were treated for $72 \mathrm{~h}$ with vincristine at their respective 72-h $\mathrm{GI}_{50}$ concentrations (SKNBe2C $32.8 \mathrm{~nm}$; SKNAS $1.5 \mathrm{~nm}$; SHSY5Y $8.2 \mathrm{nM}$ (Table 1$)$ ), $2 \mu \mathrm{M}$ verapamil or MDM2-p53 antagonists alone, or in combination, and analysed for cleaved caspase- 3 levels as a marker of apoptosis, compared with cells treated with vincristine alone (Figure 5A-C). Verapamil, Nutlin-3, NDD0005 and MI-63 potentiated vincristine-mediated apoptosis in high MDR-1-expressing p53 mutant SKNBe2C and p53 wt SHSY5Y cells, as evident by an increase in the levels of cleaved caspase- 3 (Figure $5 \mathrm{~A}$ and $\mathrm{B}$ ). In contrast, relative to vincristine alone, no increase in cleaved caspase- 3 levels were observed in p53 mutant low MDR-1-expressing SKNAS cells (Figure 5C).

Verapamil and MDM2 antagonists sensitise high MDR-1expressing p53 mutant neuroblastoma cells to doxorubicin. To confirm that the MDM2 antagonists were also able to sensitise p53 mutant high MDR-1-expressing neuroblastoma cells to an alternative MDR-1 substrate, the sensitivity of SKNBe2C and SKNAS cells to doxorubicin alone and in combination with $5 \mu \mathrm{M}$ verapamil, Nutlin-3, NDD0005, MI-63 and RG7388 was determined using XTT assays. The results demonstrated that at $5 \mu \mathrm{M}$, verapamil and all the tested MDM2 antagonists were able to significantly reduce the $\mathrm{GI}_{50}$ of doxorubicin $(P<0.05$, paired $t$-test $)$ and sensitise p53 mutant high MDR-1-expressing SKNBe2C but not low MDR-1-expressing SKNAS cells to doxorubicin (Supplementary Figure 4 and Supplementary Table 2). However, it is worth noting that the fold potentiation was not as marked as those observed for vincristine (Table 2).

NDD0005, MI-63 and RG7388 are not substrates of MDR-1. Similar to verapamil, Nutlin-3 has previously been shown to inhibit MDR-1 by acting as a competitive inhibitor (Michaelis et al, 2009); however, it is unclear whether the same is true for NDD0005, MI-63 and RG7388. Using the paired MDCKII-wt and MDCKII-MDR-1 cell lines, sensitivity to $72 \mathrm{~h}$ exposure to 
Table 2. GI 50 values for vincristine in the presence of verapamil, Nutlin-3, NDD0005, MI-63 and RG7388 in p53 mutant high MDR-1-expressing SKNBe2C and low MDR-1-expressing SKNAS, and p53 wt high MDR-1-expressing SHSY5Y neuroblastoma cells and the fold potentiation relative to vincristine alone

\begin{tabular}{|c|c|c|c|c|c|c|c|}
\hline \multirow[b]{2}{*}{ Compound } & \multirow[b]{2}{*}{ Cell line } & \multicolumn{3}{|c|}{$72 \mathrm{~h} \mathrm{Gl}_{50}$ of vincristine (nM) } & \multicolumn{3}{|c|}{ Fold potentiation } \\
\hline & & $1 \mu \mathrm{m} / 0.25 \times^{a}$ & $2 \mu \mathrm{m} / 0.5 \times^{\mathrm{a}}$ & $5 \mu \mathrm{m} / 1 \times^{a}$ & $1 \mu \mathrm{m} / 0.25 \times^{\mathrm{a}}$ & $2 \mu \mathrm{m} / 0.5 \times^{\mathrm{a}}$ & $5 \mu \mathrm{m} / 1 \times^{\mathrm{a}}$ \\
\hline Verapamil & $\begin{array}{l}\text { SKNBe2C } \\
\text { SKNAS } \\
\text { SHSY5Y }\end{array}$ & $\begin{array}{l}4.2 \pm 0.6 \\
1.2 \pm 0.1 \\
0.5 \pm 0.2\end{array}$ & $\begin{array}{l}2.2 \pm 0.3 \\
1.1 \pm 0.1 \\
0.2 \pm 0.1\end{array}$ & $\begin{array}{l}1.1 \pm 0.2 \\
0.9 \pm 0.1 \\
<0.1 \mathrm{~nm}\end{array}$ & $\begin{array}{c}10.5 \\
P<0.05 \\
1.1 \\
P=0.259 \\
10.2 \\
P<0.001\end{array}$ & $\begin{array}{c}19.9 \\
P<0.05 \\
1.1 \\
P=0.185 \\
21.8 \\
P<0.001\end{array}$ & $\begin{array}{c}38.2 \\
P<0.05 \\
1.3 \\
P=0.121 \\
>50 \\
P<0.001\end{array}$ \\
\hline Nutlin-3 & $\begin{array}{l}\text { SKNBe2C } \\
\text { SKNAS } \\
\text { SHSY5Y }\end{array}$ & $\begin{array}{l}20.1 \pm 6.2 \\
1.4 \pm 0.3 \\
2.4 \pm 0.2\end{array}$ & $\begin{array}{l}3.1 \pm 1.5 \\
1.5 \pm 0.6 \\
1.9 \pm 0.4\end{array}$ & $\begin{array}{l}1.0 \pm 0.2 \\
1.5 \pm 0.7 \\
1.4 \pm 0.3\end{array}$ & $\begin{array}{c}2.1 \\
P<0.05 \\
1.3 \\
P=0.321 \\
2.1 \\
P<0.05\end{array}$ & $\begin{array}{c}13.7 \\
P<0.005 \\
1.2 \\
P=0.109 \\
2.8 \\
P<0.05\end{array}$ & $\begin{array}{c}43.7 \\
P<0.005 \\
1.2 \\
P=0.225 \\
3.7 \\
P<0.01\end{array}$ \\
\hline NDD0005 & $\begin{array}{l}\text { SKNBe2C } \\
\text { SKNAS } \\
\text { SHSY5Y }\end{array}$ & $\begin{array}{l}2.2 \pm 0.5 \\
1.0 \pm 0.1 \\
2.3 \pm 0.7\end{array}$ & $\begin{array}{l}1.2 \pm 0.2 \\
0.8 \pm 0.1 \\
0.5 \pm 0.1\end{array}$ & $\begin{array}{c}0.7 \pm 0.2 \\
<0.1 \\
0.2 \pm 0.1\end{array}$ & $\begin{array}{c}13.0 \\
P<0.05 \\
1.2 \\
P=0.1 \\
2.4 \\
P<0.05\end{array}$ & $\begin{array}{c}23.5 \\
P<0.05 \\
1.4 \\
P<0.05 \\
12.0 \\
P<0.05\end{array}$ & $\begin{array}{c}42.4 \\
P<0.05 \\
\text { ND } \\
\text { ND } \\
33.1 \\
P<0.05\end{array}$ \\
\hline MI-63 & $\begin{array}{l}\text { SKNBe2C } \\
\text { SKNAS } \\
\text { SHSY5Y }\end{array}$ & $\begin{array}{r}22.8 \pm 3.2 \\
1.1 \pm 0.2 \\
3.9 \pm 0.8\end{array}$ & $\begin{array}{l}3.1 \pm 0.6 \\
1.0 \pm 0.1 \\
1.8 \pm 0.6\end{array}$ & $\begin{array}{l}1.0 \pm 0.1 \\
0.9 \pm 0.1 \\
0.6 \pm 0.1\end{array}$ & $\begin{array}{c}1.92 \\
P<0.001 \\
1.2 \\
P=0.664 \\
1.3 \\
P=0.096\end{array}$ & $\begin{array}{c}13.9 \\
P<0.01 \\
1.3 \\
P=0.377 \\
2.9 \\
P<0.001\end{array}$ & $\begin{array}{c}44.4 \\
P<0.01 \\
1.4 \\
P=0.242 \\
9.5 \\
P<0.01\end{array}$ \\
\hline RG7388 & $\begin{array}{l}\text { SKNBe2C } \\
\text { SKNAS } \\
\text { SHSY5Y }\end{array}$ & $\begin{array}{r}14.6 \pm 2.2 \\
1.2 \pm 0.1 \\
2.6 \pm 0.4\end{array}$ & $\begin{array}{c}18.8 \pm 2.2 \\
1 \pm 0.002 \\
2.3 \pm 0.2\end{array}$ & $\begin{array}{r}2 \pm 0.3 \\
0.9 \pm 0.1 \\
1.1 \pm 0.5\end{array}$ & $\begin{array}{c}1.8 \\
P=0.073 \\
1.0 \\
P=0.532 \\
2.0 \\
P<0.05\end{array}$ & $\begin{array}{c}1.4 \\
P=0.39 \\
1.1 \\
P=0.078 \\
2.2 \\
P<0.05\end{array}$ & $\begin{array}{c}13.3 \\
P=0.052 \\
1.2 \\
P=0.06 \\
4.8 \\
P<0.01\end{array}$ \\
\hline
\end{tabular}

Nutlin-3, NDD0005, MI-63 or RG7388 treatment was determined using SRB assays (Table 1). Consistent with the hypothesis that cells that express high levels of MDR-1 are less sensitive to MDR-1 substrates, MDCKII-MDR-1 cells were significantly less sensitive to Nutlin-3 compared with the MDCKII-wt cells (16 \pm 6.2 vs $7.2 \pm 3.3 \mu \mathrm{M}, P<0.05$, paired $t$-test). In contrast, overexpression of MDR-1 did not confer a significant resistance to NDD0005 (6.1 \pm 1.1 vs $7.1 \pm 1.7 \mu \mathrm{M}, P=0.41$ paired $t$-test), MI-63 (5.1 $\pm 2.4 v s$ $4.8 \pm 3 \mu \mathrm{M}, \quad P=0.60$, paired $t$-test) or RG7388 (238 $\pm 40.4 v s$ $145 \pm 36.1 \mathrm{~nm}, P=0.08$, paired $t$-test), which suggests that the latter compounds are not MDR-1 substrates (Table 1).

Verapamil does not sensitise high MDR-1-expressing p53 wt SHSY5Y cells to MDM2 antagonists. To determine whether the efficacy of MDM2 antagonists are affected by MDR-1 function, the sensitivity of high MDR-1-expressing p53 wt SHSY5Y cells to MDM2-p53 antagonists Nutlin-3, NDD0005, MI-63 and RG7388 alone and in combination with 1,5 or $10 \mu \mathrm{M}$ verapamil was determined using XTT assays. The concentrations of verapamil used did not affect the viability or proliferation of SHSY5Y cells when used alone (data not shown) and these concentrations have been shown to be effective at sensitising high MDR-1-expressing neuroblastoma cells to the MDR-1 substrate vincristine (Table 2).
The results demonstrated that verapamil did not sensitise SHSY5Y cells to any of the MDM2-p53 antagonists (Supplementary Figure 5).

\section{DISCUSSION}

In the last decade there has been a drive towards targeted agents in the field of cancer therapeutics. MDM2-p53-binding antagonists are one such class of novel anticancer agents currently undergoing early clinical evaluation. These inhibitors are designed to interact with the hydrophobic p53-binding pocket of MDM2, which accommodates the p53 residues Phe19, Trp23 and Leu26, thereby releasing $\mathrm{p} 53$ from the negative regulatory effect of MDM2 to carry out its growth inhibitory and pro-apoptotic activities. Nutlins were the first potent and selective inhibitors in this class (Vassilev et al, 2004) and have been shown to induce cell cycle arrest and/or apoptosis in p53 wt tumour cells both in vitro and in vivo. In addition to p53-dependent effects, some p53-independent effects have also been described, which are not reliant on the MDM2-p53 interaction and occur with both the active and inactive enantiomers of Nutlin-3 in p53 mutant or null cancer cells, and 

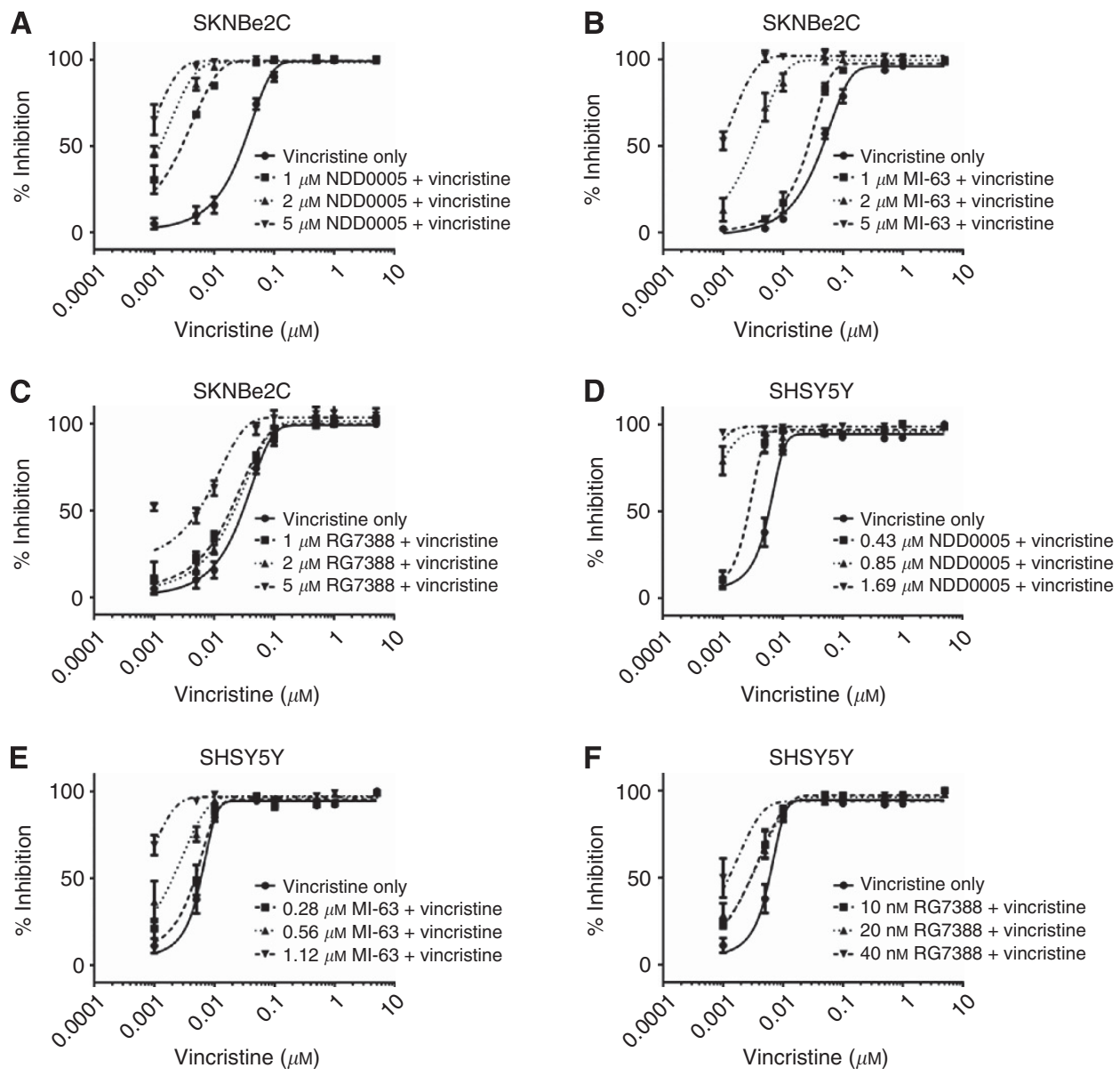

Figure 3. NDD0005 and MI-63 sensitise high MDR-1-expressing p53 mutant and wt neuroblastoma cells to vincristine in a concentrationdependent manner. Sensitivity of SKNBe2C cells to treatment for $72 \mathrm{~h}$ with vincristine alone or in combination with 1,2 or $5 \mu \mathrm{M}(\mathbf{A}) \mathrm{NDD} 0005$, (B) MI-63 or (C) RG7388. Sensitivity of SHSY5Y cells to treatment for $72 \mathrm{~h}$ with vincristine alone or in combination with $0.25 \times, 0.5 x$ and $1 \times 72-\mathrm{h}$ GI 50 concentrations of (D) NDD0005, (E) MI-63 or (F) RG7388. Data are shown as the average of at least three independent experiments and error bars represent s.e.m.

these effects include an ability to reverse MDR-1-mediated multidrug resistance (Michaelis et al, 2009).

Acquired multidrug resistance is a major cause of treatment failure, disease relapse and poor survival that affects patients with both haematological and solid malignancies. Multidrug resistance can be associated with overexpression of several members of the ATPbinding cassette transporter family such as MDR-1, MRP-1 and Breast Cancer Resistance Protein (BCRP; Szakacs et al, 2006). The best characterised member, MDR-1, has broad substrate specificity and is clinically relevant in several cancers. Identifying compounds that are potent nontoxic inhibitors of $\mathrm{ABC}$ transporters to reverse multidrug resistance has been extensively investigated and some have reached Phase II/III clinical evaluation; however, progress to date have been hindered by off-target effects and pharmacokinetic drugdrug interactions (Falasca and Linton, 2012).

In contrast to adult malignancies, the incidence of p53 mutations is low in paediatric cancers, providing a rationale for the use of MDM2-p53 antagonists as a novel therapeutic strategy in the treatment of childhood cancer. Neuroblastoma is largely a p53 wt tumour; however, an increase in the frequency of mutations has been reported at relapse (Tweddle et al, 2001a; Carr-Wilkinson et al, 2010). We and others have previously demonstrated the potent effects of MDM2-p53 antagonists on neuroblastoma cells with wt p53 (Van Maerken et al, 2006; Van Maerken et al, 2009; Van Maerken et al, 2011; Gamble et al, 2012). Here, using predominantly p53 mutant neuroblastoma cell lines established at relapse with varying MDR-1 expression as a model of chemoresistant disease, this study confirms and extends the original observations by Michaelis et al (2009), demonstrating that Nutlin-3 is an inhibitor of MDR-1 function and sensitises high MDR-1-expressing cells to vincristine-mediated cytotoxicity in a concentration-dependent manner. Furthermore, the present study demonstrates for the first time that in addition to Nutlin-3 other structurally unrelated MDM2-p53 antagonists can also modulate MDR-1 function in a concentration-dependent manner. This property is of particular clinical relevance as several MDM2-p53 antagonists are currently in, or will soon enter early-phase clinical evaluation, and if successful will most likely be used in combination with existing chemotherapeutics, some of which are known to be MDR-1 substrates, such as vincristine or doxorubicin.

RG7388 (Ding et al, 2013), a pyrrolidine scaffold compound currently in Phase I clinical trials for patients with advanced malignancies except leukaemia (www.clinicaltrials.gov; NCT01462175), was the only MDM2-p53 antagonist that did not significantly sensitise high MDR-1-expressing cells to vincristine or increase intracellular levels of vincristine. However, when RG7388 was used at the highest tested concentration of $5 \mu \mathrm{M}$ with vincristine, a borderline significant 13 -fold sensitisation was observed. This suggests that RG7388 is not as potent as the other MDM2-p53 antagonists at inhibiting MDR-1 function but can still do so at higher concentrations. It is noteworthy that RG7388 shares some structural features with MI-63, a spiro-oxindole that is an MDR-1 inhibitor (Ding et al, 2013). 
A

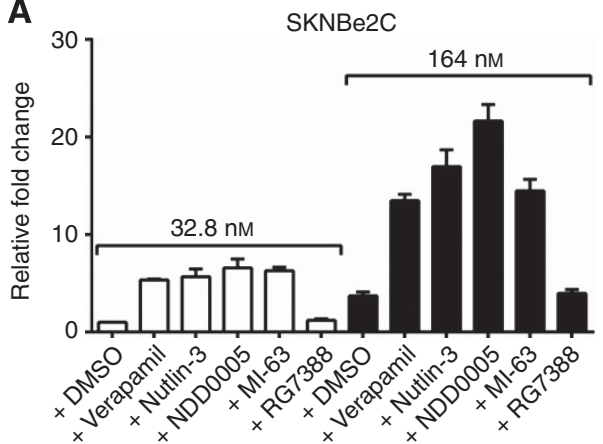

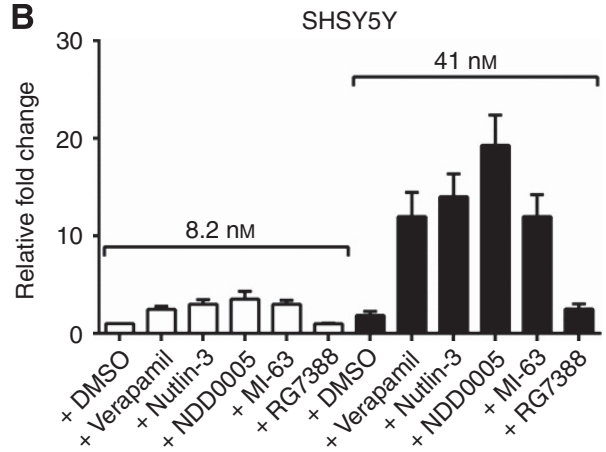

C

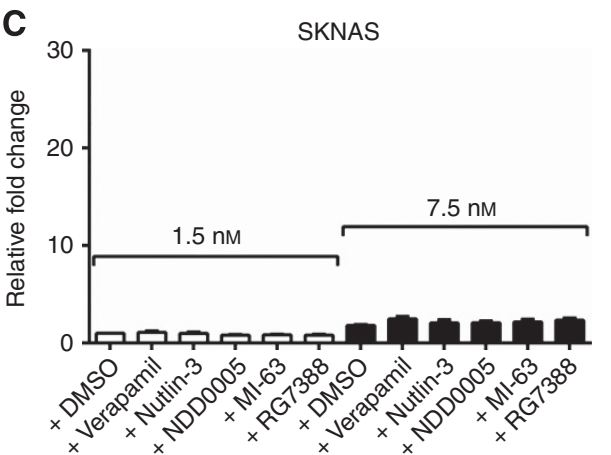

D

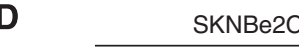

SKNAS

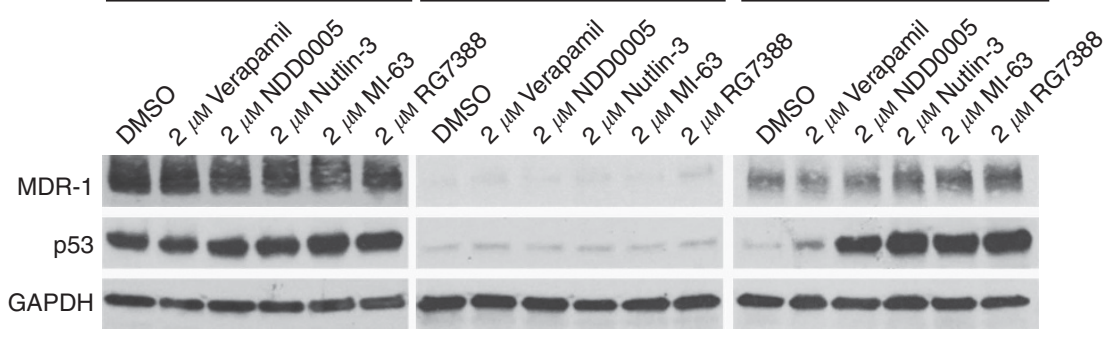

Figure 4. Verapamil and MDM2-p53 antagonists Nutlin-3, NDD0005 and MI-63 increase intracellular vincristine levels in high MDR-1-expressing neuroblastoma cells but not in low MDR-1-expressing cells. Intracellular levels of vincristine in (A) SKNBe2C, (B) SHSY5Y and (C) SKNAS cells treated for $8 \mathrm{~h}$ with $1 \times$ or $5 \times$ their respective 72-h vincristine Gl 50 concentrations (SKNBe2C 32.8/164 nm; SHSY5Y 8.2/41 nm; SKNAS 1.5/7.5 nm) alone or in combination with $2 \mu \mathrm{m}$ verapamil, Nutlin-3, NDD0005, MI-63 or RG7388. Data are expressed relative to cells treated with $1 \times$ vincristine $\mathrm{Gl}_{50}$ concentration alone. Data are shown as the average of at least three independent experiments \pm s.e.m. (D) Western blot analysis showing MDR-1 and p53 expression in SKNBe2C, SKNAS and SHSY5Y cells after treatment with $2 \mu \mathrm{m}$ each of verapamil, NDD0005, Nutlin-3, MI-63 or RG7388 for $8 \mathrm{~h}$.

RG7112 is based on a cis-imidazoline scaffold such as Nutlin-3 and has undergone clinical evaluation in early-phase trials as a single agent and in combination with doxorubicin (www.clinicaltrials.gov; NCT01677780 and NCT01605526; RayCoquard et al, 2012). Doxorubicin has previously been reported as a substrate of MDR-1, and the efficacy results of current trials should be interpreted in the light of the study by Michaelis et al (2009), which found that Nutlin-3 can also sensitise mutant p53 cells to doxorubicin-mediated cytotoxicity, although the magnitude was not as great as observed with vincristine. Consistent with this result, our analysis of doxorubicin in combination with the MDM2-p53 antagonists demonstrated that sensitisation was also not as marked as that observed for vincristine (Supplementary Figure 4 and Supplementary Table 2).

ABC transporters are expressed in cells of the liver, kidneys, gastrointestinal tract and the epithelium of the blood-brain barrier (Schinkel, 1999), therefore affecting drug pharmacokinetics and efficacy. If MDM2-p53 inhibitors with the ability to modulate MDR-1 function are used in combination with cytotoxic drugs that are MDR-1 substrates, altered pharmacokinetics, efficacy and potentially toxic drug-drug interactions should be considered, particularly an increased risk of neurotoxicity with vincristine. Studies have demonstrated that $m d r-1$ knockout mice are highly sensitive to a range of MDR-1 substrates compared with wt mice (Schinkel, 1999).

Expression of MDR-1 has recently been shown to confer resistance to YM155, an inhibitor of Survivin, in neuroblastoma cells. Inhibition of MDR-1 led to sensitisation of MDR-1overexpressing cell lines to YM155 (Lamers et al, 2012). It would be interesting to determine whether combining an MDM2-p53 antagonist with an inhibitor of Survivin would lead to synergistic tumour cell killing.
In addition to modulating MDR-1 activity, Nutlin-3 has also previously been shown to affect MRP-1 and BCRP function (Michaelis et al, 2009; Zhang et al, 2011). Analysis of MRP-1 protein expression in the panel of cell lines used in this study demonstrated that there was no marked difference in MRP-1 expression between the cell lines (Supplementary Figure 1). BCRP expression was not analysed in the present study and it is possible that other MDM2-p53 antagonists may also be able to modulate the activity of additional ABC transporters.

The current study has also shown that despite the ability of MDM2-p53 antagonists to affect MDR-1 activity and sensitise high MDR-1-expressing cells to MDR-1 substrates, combining MDM2-p53 antagonists, Nutlin-3, NDD005, MI-63 and RG7388 with verapamil did not further sensitise p53 wt high MDR-1expressing SHSY5Y cells to the MDM2-p53 antagonists. This result is consistent with observations that NDD005, MI-63 and RG7388 are not substrates of MDR-1. The lack of a sensitising effect with Nutlin-3, which is an MDR-1 substrate (Michaelis et al, 2009), may be due to the relative affinities of Nutlin-3 vs verapamil for MDR-1, or that p53 wt cells are already highly sensitive to Nutlin-3-mediated growth inhibition such that modulating MDR-1 function has no additional effect.

In contrast to previous studies which have shown that wt p53 represses MDR-1 expression (Thottassery et al, 1997; Johnson et al, 2001; Vilgelm et al, 2008), treatment of p53 wt SHSY5Y cells in the present study with MDM2-p53 antagonists for $8 \mathrm{~h}$ led to stabilisation of p53 but did not result in a decrease in MDR-1 expression. Furthermore, in contrast to studies that have shown that treatment with verapamil can lead to decreased MDR-1 expression (Muller et al, 1994; Yu et al, 2008), in this study treatment of high MDR-1-expressing SHSY5Y and SKNBe2C cells did not alter MDR-1 expression. 
A$$
\text { A }
$$

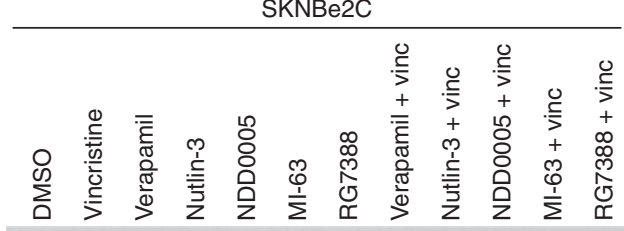

Cleaved caspase-3

GAPDH

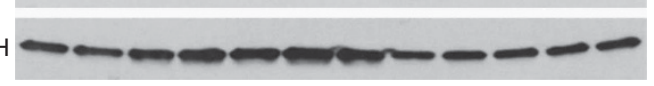

B

SHSY5Y

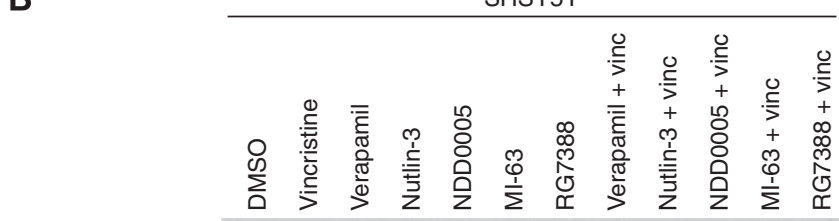

Cleaved caspase-3

GAPDH

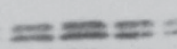

GAPDH

C

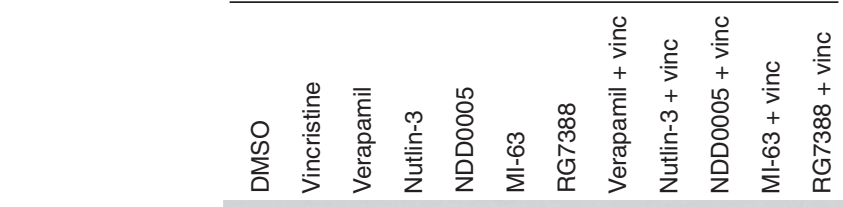

Cleaved caspase-3

GAPDH

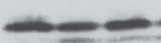

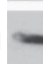

Figure 5. Verapamil and MDM2-p53 antagonists Nutlin-3, NDD0005 and Ml-63 sensitise high MDR-1-expressing neuroblastoma cells but not low MDR-1-expressing cells to vincristine-mediated apoptosis. Western blot analysis showing the levels of cleaved caspase-3 as a marker of apoptosis in (A) SKNBe2C, (B) SHSY5Y and (C) SKNAS cells treated for $72 \mathrm{~h}$ with $1 \times$ their respective $72-\mathrm{h}$ vincristine $\mathrm{GI}_{50}$ concentrations (SKNBe2C $32.8 \mathrm{~nm}$; SHSY5Y $8.2 \mathrm{~nm}$; SKNAS $1.5 \mathrm{~nm}$ ) or $2 \mu \mathrm{M}$ verapamil, Nutlin-3, NDD0005, MI-63 or RG7388 alone, or in combination. GAPDH was used as a loading control.

However, it is possible that extended treatment periods more than $8 \mathrm{~h}$ are necessary to observe a reduction in MDR-1 expression.

Overall, this study demonstrates that the susceptibility of cytotoxic drugs to MDR-1-mediated transport should be considered when designing clinical trials with combination regimens including MDM2-p53 antagonists. Furthermore, these studies suggest that certain classes of MDM2-p53 antagonists combined with vincristine may be useful against p53 mutant tumours that express high levels of MDR-1, as demonstrated here particularly with the isoindolinone class. These findings have relevance for the development of both MDM2-p53 antagonists and MDR-1 or other ABC transporter inhibitors and their clinical evaluation. Future studies that extend the current in vitro observations into in vivo models are warranted.

\section{ACKNOWLEDGEMENTS}

We thank The Dubois Child Cancer Fund, SPARKS, the JGW Paterson Foundation, North of England's Children's Research Fund, Cancer Research UK and the University of Camerino
(Fondo di Ateneo per la Ricerca 2011-2012) for funding this work. We thank Anna Watson, Karen Haggerty and Ian Hardcastle for synthesising NDD0005, and the following for providing cell lines, Jean Bénard (SKNAS, LAN1 and IGRN91), Penny Lovat (SHSY5Y), Barbara Spengler (SKNBe2C) and Alfred Schinkel (MDCKII-wt, MDCKII-MDR-1 and MDCKII-MRP-1). Finally, we also thank other members of the Roche Paediatric MDM2-p53 Inhibitor Consortium, Andrew Pearson, Louis Chesler, Lucas Moreno, Jason Shohet, Tom Van Maerken and Johannes Schulte for their helpful discussions.

\section{CONFLICT OF INTEREST}

L Chen and DA Tweddle are part of an international collaborative research consortium with Hoffmann-La Roche Inc. DR Newell is co-director of the CRUK funded Drug Discovery Programme at Newcastle University which developed NDD0005 and in which J Lunec and DA Tweddle are collaborative co-investigators. Newcastle University, Cancer Research Technology and Astex Pharmaceuticals Inc. are part of an alliance agreement since 2012 and DR Newell has received research funding from Astex Pharmaceuticals, Inc. RF Rousseau is employed by Genentech Inc., and SA Middleton and GL Nichols are employed by Hoffmann-La Roche. The remaining authors declare no conflict of interest.

\section{REFERENCES}

Ambrosini G, Sambol EB, Carvajal D, Vassilev LT, Singer S, Schwartz GK (2007) Mouse double minute antagonist Nutlin-3a enhances chemotherapy-induced apoptosis in cancer cells with mutant p53 by activating E2F1. Oncogene 26(24): 3473-3481.

Bakos E, Evers R, Szakacs G, Tusnady GE, Welker E, Szabo K, de Haas M, van Deemter L, Borst P, Varadi A, Sarkadi B (1998) Functional multidrug resistance protein (MRP1) lacking the N-terminal transmembrane domain. J Biol Chem 273(48): 32167-32175.

Benard J, Bourhis J, de Vathaire F, Ferrandis E, Terrier-Lacombe MJ, Lemerle J, Riou G, Hartmann O (1994) Prognostic value of MDR1 gene expression in neuroblastoma: results of a multivariate analysis. Prog Clin Biol Res 385: 111-116.

Breier A, Gibalova L, Seres M, Barancik M, Sulova Z (2013) New insight into p-glycoprotein as a drug target. Anticancer Agents Med Chem 13(1): 159-170.

Carr-Wilkinson J, O'Toole K, Wood KM, Challen CC, Baker AG, Board JR, Evans L, Cole M, Cheung NK, Boos J, Kohler G, Leuschner I, Pearson AD, Lunec J, Tweddle DA (2010) High frequency of p53/MDM2/p14ARF pathway abnormalities in relapsed neuroblastoma. Clin Cancer Res 16(4): 1108-1118.

Chan HS, Haddad G, Thorner PS, DeBoer G, Lin YP, Ondrusek N, Yeger H, Ling V (1991) P-glycoprotein expression as a predictor of the outcome of therapy for neuroblastoma. N Engl J Med 325(23): 1608-1614.

Chen L, Tweddle DA (2012) p53, SKP2, and DKK3 as MYCN target genes and their potential therapeutic significance. Front Oncol 2: 173.

Cheok CF, Verma CS, Baselga J, Lane DP (2011) Translating p53 into the clinic. Nat Rev Clin Oncol 8(1): 25-37.

deCremoux P, Jourdan-Da-Silva N, Couturier J, Tran-Perennou C, Schleiermacher G, Fehlbaum P, Doz F, Mosseri V, Delattre O, Klijanienko J, Vielh P, Michon J (2007) Role of chemotherapy resistance genes in outcome of neuroblastoma. Pediatr Blood Cancer 48(3): 311-317.

Ding K, Lu Y, Nikolovska-Coleska Z, Wang G, Qiu S, Shangary S, Gao W, Qin D, Stuckey J, Krajewski K, Roller PP, Wang S (2006) Structure-based design of spiro-oxindoles as potent, specific small-molecule inhibitors of the MDM2-p53 interaction. J Med Chem 49(12): 3432-3435.

Ding Q, Zhang Z, Liu JJ, Jiang N, Zhang J, Ross TM, Chu XJ, Bartkovitz D, Podlaski FJ, Janson C, Tovar C, Filipovic ZM, Higgins B, Glenn K, Packman K, Vassilev L, Graves B (2013) Discovery of RG7388, a potent and selective p53-MDM2 inhibitor in clinical development. J Med Chem 56(14): 5979-5983. 
Falasca M, Linton KJ (2012) Investigational ABC transporter inhibitors. Exp Opin Invest Drugs 21(5): 657-666.

Gamble LD, Kees UR, Tweddle DA, Lunec J (2012) MYCN sensitizes neuroblastoma to the MDM2-p53 antagonists Nutlin-3 and MI-63. Oncogene 31(6): 752-763.

Goldschneider D, Horvilleur E, Plassa L-F, Guillaud-Bataille M, Million K, Wittmer-Dupret E, Danglot G, de The H, Benard J, May E, Douc-Rasy S (2006) Expression of C-terminal deleted p53 isoforms in neuroblastoma. Nucleic Acids Res 34(19): 5603-5612.

Haber M, Bordow SB, Haber PS, Marshall GM, Stewart BW, Norris MD (1997) The prognostic value of MDR1 gene expression in primary untreated neuroblastoma. Eur J Cancer 33(12): 2031-2036.

Hardcastle IR, Ahmed SU, Atkins H, Calvert AH, Curtin NJ, Farnie G, Golding BT, Griffin RJ, Guyenne S, Hutton C, Kallblad P, Kemp SJ, Kitching MS, Newell DR, Norbedo S, Northen JS, Reid RJ, Saravanan K, Willems HM, Lunec J (2005) Isoindolinone-based inhibitors of the MDM2-p53 protein-protein interaction. Bioorg Med Chem Lett 15(5): $1515-1520$.

Israels T, Damen CW, Cole M, van Geloven N, Boddy AV, Caron HN, Beijnen JH, Molyneux EM, Veal GJ (2010) Malnourished Malawian patients presenting with large Wilms tumours have a decreased vincristine clearance rate. Eur J Cancer 46(10): 1841-1847.

Johnson RA, Ince TA, Scotto KW (2001) Transcriptional repression by p53 through direct binding to a novel DNA element. J Biol Chem 276(29): 27716-27720.

Lamers F, Schild L, Koster J, Versteeg R, Caron HN, Molenaar JJ (2012) Targeted BIRC5 silencing using YM155 causes cell death in neuroblastoma cells with low ABCB1 expression. Eur J Cancer 48(5): 763-771.

Lau LM, Nugent JK, Zhao X, Irwin MS (2008) HDM2 antagonist Nutlin-3 disrupts p73-HDM2 binding and enhances p73 function. Oncogene 27(7): 997-1003.

Michaelis M, Rothweiler F, Klassert D, von Deimling A, Weber K, Fehse B, Kammerer B, Doerr HW, Cinatl Jr. J (2009) Reversal of P-glycoproteinmediated multidrug resistance by the murine double minute 2 antagonist nutlin-3. Cancer Res 69(2): 416-421.

Miyazaki M, Naito H, Sugimoto Y, Yoshida K, Kawato H, Okayama T, Shimizu H, Miyazaki M, Kitagawa M, Seki T, Fukutake S, Shiose Y, Aonuma M, Soga T (2013) Synthesis and evaluation of novel orally active p53-MDM2 interaction inhibitors. Bioorg Med Chem 21(14): 4319-4331.

Muller C, Bailly JD, Goubin F, Laredo J, Jaffrezou JP, Bordier C, Laurent G (1994) Verapamil decreases P-glycoprotein expression in multidrugresistant human leukemic cell lines. Int J Cancer 56(5): 749-754.

Oue T, Yoneda A, Uehara S, Yamanaka H, Fukuzawa M (2009) Increased expression of multidrug resistance-associated genes after chemotherapy in pediatric solid malignancies. J Pediatr Surg 44(2): 377-380.

Park JR, Eggert A, Caron H (2010) Neuroblastoma: biology, prognosis, and treatment. Hematol Oncol Clin North Am 24(1): 65-86.

Peirce SK, Findley HW (2009) The MDM2 antagonist nutlin-3 sensitizes p53-null neuroblastoma cells to doxorubicin via E2F1 and TAp73. Int J Oncol 34(5): 1395-1402.

Ray-Coquard I, Blay JY, Italiano A, Le Cesne A, Penel N, Zhi J, Heil F, Rueger R, Graves B, Ding M, Geho D, Middleton SA, Vassilev LT, Nichols GL, Bui BN (2012) Effect of the MDM2 antagonist RG7112 on the P53 pathway in patients with MDM2-amplified, well-differentiated or dedifferentiated liposarcoma: an exploratory proof-of-mechanism study. Lancet Oncol 13(11): 1133-1140.

Schinkel AH (1999) P-Glycoprotein, a gatekeeper in the blood-brain barrier. Adv Drug Deliv Rev 36(2-3): 179-194.

Szakacs G, Paterson JK, Ludwig JA, Booth-Genthe C, Gottesman MM (2006) Targeting multidrug resistance in cancer. Nat Rev Drug Discov 5(3): 219-234.
Thottassery JV, Zambetti GP, Arimori K, Schuetz EG, Schuetz JD (1997) p53-dependent regulation of MDR1 gene expression causes selective resistance to chemotherapeutic agents. Proc Natl Acad Sci USA 94(20): 11037-11042.

Tsuruo T, Iida H, Tsukagoshi S, Sakurai Y (1981) Overcoming of vincristine resistance in P388 leukaemia in vivo and in vitro through enhanced cytotoxicity of vincristine and vinblastine by verapamil. Cancer Res 41(5): 1967-1972.

Tweddle DA, Malcolm AJ, Bown N, Pearson AD, Lunec J (2001a) Evidence for the development of p53 mutations after cytotoxic therapy in a neuroblastoma cell line. Cancer Res 61(1): 8-13.

Tweddle DA, Malcolm AJ, Cole M, Pearson AD, Lunec J (2001b) p53 cellular localization and function in neuroblastoma: evidence for defective $\mathrm{G}(1)$ arrest despite WAF1 induction in MYCN-amplified cells. Am J Pathol 158(6): 2067-2077.

Van Maerken T, Ferdinande L, Taildeman J, Lambertz I, Yigit N, Vercruysse L, Rihani A, Michaelis M, Cinatl Jr. J, Cuvelier CA, Marine JC, De Paepe A, Bracke M, Speleman F, Vandesompele J (2009) Antitumor activity of the selective MDM2 antagonist nutlin-3 against chemoresistant neuroblastoma with wild-type p53. J Natl Cancer Inst 101(22): 1562-1574.

Van Maerken T, Rihani A, Dreidax D, De Clercq S, Yigit N, Marine JC, Westermann F, De Paepe A, Vandesompele J, Speleman F (2011) Functional analysis of the p53 pathway in neuroblastoma cells using the small-molecule MDM2 antagonist nutlin-3. Mol Cancer Ther 10(6): 983-993.

Van Maerken T, Speleman F, Vermeulen J, Lambertz I, De Clercq S, De Smet E, Yigit N, Coppens V, Philippe J, De Paepe A, Marine JC, Vandesompele J (2006) Small-molecule MDM2 antagonists as a new therapy concept for neuroblastoma. Cancer Res 66(19): 9646-9655.

Vassilev LT (2004) Small-molecule antagonists of p53-MDM2 binding: research tools and potential therapeutics. Cell Cycle 3(4): 419-421.

Vassilev LT, Vu BT, Graves B, Carvajal D, Podlaski F, Filipovic Z, Kong N, Kammlott U, Lukacs C, Klein C, Fotouhi N, Liu EA (2004) In vivo activation of the p53 pathway by small-molecule antagonists of MDM2. Science 303(5659): 844-848.

Vilgelm A, Wei JX, Piazuelo MB, Washington MK, Prassolov V, El-Rifai W, Zaika A (2008) DeltaNp73alpha regulates MDR1 expression by inhibiting p53 function. Oncogene 27(15): 2170-2176.

Watson AF, Liu J, Bennaceur K, Drummond CJ, Endicott JA, Golding BT, Griffin RJ, Haggerty K, Lu X, McDonnell JM, Newell DR, Noble ME, Revill CH, Riedinger C, Xu Q, Zhao Y, Lunec J, Hardcastle IR (2011) MDM2-p53 protein-protein interaction inhibitors: a-ring substituted isoindolinones. Bioorg Med Chem Lett 21(19): 5916-5919.

Yu M, Ocana A, Tannock IF (2013) Reversal of ATP-binding cassette drug transporter activity to modulate chemoresistance: why has it failed to provide clinical benefit? Cancer Metastasis Rev 32(1-2): 211-227.

Yu XN, Chen XL, Li H, Li XX, Li HQ, Jin WR (2008) Reversion of $\mathrm{P}$-glycoprotein-mediated multidrug resistance in human leukemic cell line by carnosic acid. Chin J Physiol 51(6): 348-356.

Zhang F, Throm SL, Murley LL, Miller LA, Steven Zatechka Jr D, Kiplin Guy R, Kennedy R, Stewart CF (2011) MDM2 antagonist nutlin-3a reverses mitoxantrone resistance by inhibiting breast cancer resistance protein mediated drug transport. Biochem Pharmacol 82(1): 24-34.

This work is published under the standard license to publish agreement. After 12 months the work will become freely available and the license terms will switch to a Creative Commons AttributionNonCommercial-Share Alike 3.0 Unported License.

Supplementary Information accompanies this paper on British Journal of Cancer website (http://www.nature.com/bjc) 